\title{
SYNTHESIS, ANTIMICROBIAL AND ANTICANCER ACTIVITIES OF 5-(4-SUBSTITUTED-PHENYL)-1,3,4- THIADIAZOLE-2-AMINES
}

\author{
P. K. Upadhyay* and P. Mishra \\ Institute of Pharmaceutical Research, GLA University, Mathura-281406, U.P., India \\ *E-mail: pkutanu@gmail.com
}

\begin{abstract}
A series of 5-(4-substituted phenyl)-1,3,4-thiadiazole-2-amines (4a-h) were prepared from dehydrocyclization of 4substituted benzoyl thiosemicarbazides (3a-h) using concentrated sulphuric acid. The chemical structures of compounds were elucidated by Infra-red, NMR, Mass spectral and elemental analyses. Antibacterial activities of these compounds against Staphylococcus aureus, Bacillus substilis, Eschereria coli and Pseudomonas aeruginosa using Ciprofloxacin while antifungal activities against Aspergillus niger and Candida albicans using Fluconazole as standard drugs were performed. Minimum inhibitory concentrations and anticancer activity of potent compounds was determined.

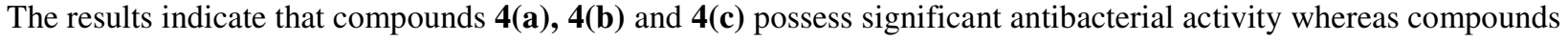
$\mathbf{4}(\mathbf{f})$ and $\mathbf{4}(\mathrm{g})$ possess significant antifungal activity among the series of synthesized thiadiazoles comparing with standard drugs. Further, the results of anticancer studies on breast cancer cell line suggested that some potent antimicrobials i.e. $\mathbf{4 ( c ) ,} \mathbf{4 ( f )}$ and $\mathbf{4 ( g )}$ associated with moderate to good anticancer activity. Thus, it may be found that synthesized compounds have good antibacterial activity and moderate antifungal activity. However, these compounds could be further screened for the antibacterial activities against a battery of bacteria to achieve their broad spectrum profile and also used to screen cytotoxic effect against other cancer cell lines.
\end{abstract}

Keywords: Synthesis, thiadiazole, antimicrobial, cytotoxic, cancer cell line.

(C) RASĀYAN. All rights reserved

\section{INTRODUCTION}

Mankind has been invaded by infectious diseases since ages. To counteract these infections, a large number of antimicrobial drugs have been invented by scientists. However, the change in the lifecycle of microbes and the resistance developed thereafter has become a serious issue ${ }^{1}$. There is always a necessity to search better antimicrobial agents and the inventions of such drugs have an important role in medicinal chemistry $^{2}$. Sulfur containing heterocyclic compounds 1,3,4-thiadiazoles are the valuable structural part of bioactive compounds ${ }^{3}$. 5-Phenyl-1,3,4-thiadiazole is familiar group of bioactive compounds with numerous pharmacological activities ${ }^{4}$.

Various pharmacological activities reported for 1,3,4-thiadiazole analogues are anticancer ${ }^{5-7}$ antimicrobial $^{8-10}$, antitubercular ${ }^{11,12}$, anti-inflammatory ${ }^{13}$, analgesic ${ }^{14}$, anticonvulsant ${ }^{15}$, antihypertensive ${ }^{16}$, diuretic $^{17}$, local anesthetic ${ }^{18}$ and antioxidant activities ${ }^{19}$.Hence, it is envisaged to synthesize 1,3,4thiadiazole analogs and screened them for antimicrobial and anticancer activities.

\section{EXPERIMENTAL}

All chemicals and solvents were procured from Merck Chemicals, Spectrochem (P) Ltd. and Qualigens Chemicals, Mumbai, India. Purity of these compounds was checked by thin layer chromatography (TLC) on silica gel $G$ glass plates for which iodine vapors was the detecting agent. $R_{f}$ values of synthesized compounds were found by taking different proportions of benzene and acetone (Table-1). The synthesized compounds were recrystallized from ethanol and water mixtures. Melting points of all the synthesized compounds were determined in open capillaries and are uncorrected. Structures of intermediates were established on the basis of melting point and various functional groups test. Infra-red spectra (in $\mathrm{KBr}$ ) 
were determined on a Shimadzu IR Affinity-1 FTIR spectrophotometer. ${ }^{13} \mathrm{C}$ NMR spectra in dimethyl sulphoxide (DMSO) were recorded at strength of $400 \mathrm{MHz}$ on Jeol-JMS spectrometer using TMS as an reference standard ((chemical shift, $\delta$ ppm). Mass spectra were scanned on Shimadzu LC-MS 2010A spectrometer. The percentage estimation of carbon, hydrogen, nitrogen and sulphur were determined using Euro-Vector EA-3000 analyzer. The elemental analyses for C, H, N and S established for these compounds were established to be within $\pm 0.5 \%$ limits of theoretical values.

\section{General method for the synthesis of methyl 4-substituted benzoate, 2(a-h)}

The 4-substituted benzoates $\mathbf{2}(\mathbf{a}-\mathbf{h})$ were prepared according to reported procedure ${ }^{20}$. These esters were used for the synthesis of the intermediate, benzoyl thiosemicarbazides.

\section{General method for the synthesis of 4-substituted benzoyl thiosemicarbazide 3 (a-h)}

The 4-substituted benzoyl thiosemicarbazides were synthesized according to reported methods ${ }^{21,22}$. The thiosemicarbazide $(0.015 \mathrm{~mol})$ and benzoic acid esters $(0.01 \mathrm{~mol})$ were dissolved in $50 \mathrm{~mL}$ of methanol by heating. Then, reaction mixture was refluxed for 8-10 h. The ice-water mixture was added to resulting solution. The solid which got separated was dried and recrystallized using rectified spirit.

\section{General method for synthesis of 2- amino 5-(4-substituted phenyl)-1, 3, 4-thiadiazole ${ }^{23,24}$ 4(a-h)}

The 4-substituted benzoyl thiosemicarbazide $(0.02 \mathrm{~mol})(\mathbf{3 a}-\mathbf{h})$ was added portion wise to concentrated sulphuric acid $(20 \mathrm{~mL})$ with shaking. The mixture was heated between $60-70^{\circ} \mathrm{C}$ for $5 \mathrm{~h}$. The reaction mixture was kept aside at room temperature overnight. This solution was poured over crushed ice. The compound was precipitated by addition of $\mathrm{NH}_{4} \mathrm{OH}$ solution. The precipitate, so obtained was washed thoroughly with distilled water to free from the sulphates. The dried product was recrystallized from chloroform.

The physical constants and data of the title compounds are provided in Table-1.

Table-1: Physical Properties of 5-(4-substituted phenyl)-1, 3, 4-thiadiazole-2-amines, 4(a-h):<smiles>[R]c1ccc(-c2nnc(N)s2)cc1</smiles>

\begin{tabular}{c|c|c|c|c|c|c|c}
\hline Compounds & $\mathrm{R}$ & $\begin{array}{c}\text { Molecular } \\
\text { Formula }\end{array}$ & $\begin{array}{c}\text { Molecular } \\
\text { Weight }\end{array}$ & $\begin{array}{c}\text { Yield } \\
(\%)\end{array}$ & $\begin{array}{c}\text { M.P. } \\
\left({ }^{\circ} \mathrm{C}\right)\end{array}$ & $\begin{array}{c}\mathrm{R}_{\mathrm{f}} \\
\text { Value }\end{array}$ & $\begin{array}{c}\text { Benzene:Ac } \\
\text { etone }\end{array}$ \\
\hline $4(\mathrm{a})$ & $\mathrm{F}$ & $\mathrm{C}_{8} \mathrm{H}_{6} \mathrm{FN} \mathrm{S}_{3} \mathrm{~S}$ & 195.22 & 63.6 & $233-35$ & 0.77 & $8: 2$ \\
\hline $4(\mathrm{~b})$ & $\mathrm{Cl}$ & $\mathrm{C}_{8} \mathrm{H}_{6} \mathrm{ClN}_{3} \mathrm{~S}$ & 211.67 & 66.4 & $227-29$ & 0.83 & $9: 1$ \\
\hline $4(\mathrm{c})$ & $\mathrm{Br}$ & $\mathrm{C}_{8} \mathrm{H}_{6} \mathrm{BrN}_{3} \mathrm{~S}$ & 256.12 & 72.4 & $224-26$ & 0.80 & $9: 1$ \\
\hline $4(\mathrm{~d})$ & $\mathrm{I}$ & $\mathrm{C}_{8} \mathrm{H}_{6} \mathrm{IN}_{3} \mathrm{~S}$ & 303.12 & 78.2 & $282-84$ & 0.86 & $9: 1$ \\
\hline $4(\mathrm{e})$ & $\mathrm{CH}_{3}$ & $\mathrm{C}_{9} \mathrm{H}_{9} \mathrm{~N}_{3} \mathrm{~S}$ & 191.25 & 70.5 & $218-20$ & 0.78 & $8: 2$ \\
\hline $4(\mathrm{f})$ & $\mathrm{OH}$ & $\mathrm{C}_{8} \mathrm{H}_{7} \mathrm{~N}_{3} \mathrm{OS}$ & 193.23 & 65.8 & $214-16$ & 0.66 & $7: 3$ \\
\hline $4(\mathrm{~g})$ & $\mathrm{OCH}_{3}$ & $\mathrm{C}_{9} \mathrm{H}_{9} \mathrm{~N}_{3} \mathrm{OS}$ & 207.25 & 73.4 & $225-27$ & 0.72 & $7: 3$ \\
\hline $4(\mathrm{~h})$ & $\mathrm{OC}_{2} \mathrm{H}_{5}$ & $\mathrm{C}_{10} \mathrm{H}_{11} \mathrm{~N}_{3} \mathrm{OS}$ & 221.06 & 75.2 & $238-40$ & 0.68 & $8: 2$ \\
\hline
\end{tabular}

Spectral data and elemental analysis data of title compounds (4 a-h) are presented as follows:

5-(4-Fluoro-phenyl)-[1, 3, 4]thiadiazole-2-amine (4a)

IR $\left(\mathrm{KBr} v, \mathrm{~cm}^{-1}\right): 3372(\mathrm{~N}-\mathrm{H}$ stretching $), 3064(\mathrm{C}-\mathrm{H}$ str, aromatic $), 1632(\mathrm{C}=\mathrm{N}$ str, ring) 1562-1448 $(\mathrm{C}=\mathrm{C}$ str, aromatic), 1056 (C-F str), 862 (C-S-C str, thiadiazole); ${ }^{13} \mathrm{C}$ NMR $400 \mathrm{MHz},\left(\mathrm{DMSO}-\mathrm{d}_{6}, \delta, \mathrm{ppm}\right.$ ): 
175.2 (C-5), 163.1 (C-4'), 162.2 (C-2), 130.3 (C-2',C-6'), 129.8 (C-1'), 117.1 (C-3',C-5'); LCMS (m/z): $195\left(\mathrm{M}^{+}\right), 196\left(\mathrm{M}^{+}+1\right)$; Elemental Analysis $\left(\mathrm{C}_{8} \mathrm{H}_{6} \mathrm{FN}_{3} \mathrm{~S}\right)$, Found \% (Calculated \%): C, 49.04 (49.22); H, 3.06 (3.10); N, 21.42 (21.52); S, 16.36 (16.43).

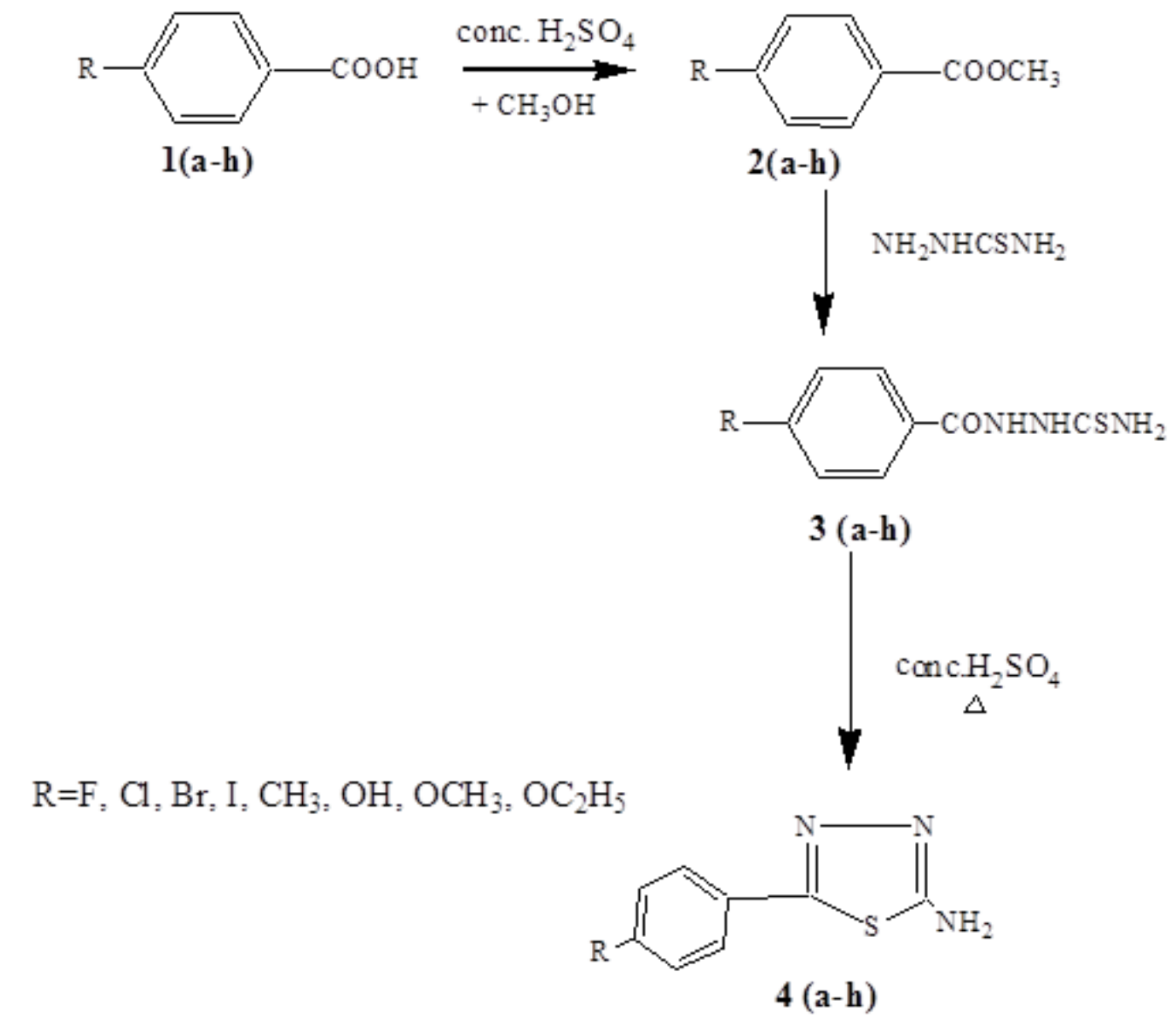

Scheme-1: Synthesis of 5-Phenyl-1, 3, 4-thiadiazole-2-amines 4 (a-h)

\section{5-(4-Chloro-phenyl)-[1, 3, 4] thiadiazole-2-amine (4b)}

IR $\left(\mathrm{KBr} v, \mathrm{~cm}^{-1}\right): 3378(\mathrm{~N}-\mathrm{H}$ stretching), $3064(\mathrm{C}-\mathrm{H}$ str, aromatic), $1634(\mathrm{C}=\mathrm{N}$ str, ring) 1562-1448 $(\mathrm{C}=\mathrm{C}$ str, aromatic), 880 (C-S-C str, thiadiazole), 761 (C-Cl str); ${ }^{13} \mathrm{C}$ NMR $400 \mathrm{MHz}$, (DMSO-d 6 , $\delta$, ppm): 174.2 (C-5), 162.3 (C-2), 135.1 (C-4'), 132.3 (C-1'), 129.8 (C-3',C-5'), 128.2 (C-2',C-6'); LCMS (m/z): 211 $\left(\mathrm{M}^{+}\right), 213\left(\mathrm{M}^{+}+2\right)$; Elemental Analysis $\left(\mathrm{C}_{8} \mathrm{H}_{6} \mathrm{ClN}_{3} \mathrm{~S}\right)$, Found \% (Calculated \%): $\mathrm{C}, 45.22$ (45.39); H, 2.82 (2.86); N, 19.78 (19.85); S, 15.10 (15.15).

\section{5-(4-Bromo-phenyl)-[1, 3, 4] thiadiazole-2-amine (4c)}

IR $\left(\mathrm{KBr} v, \mathrm{~cm}^{-1}\right): 3381(\mathrm{~N}-\mathrm{H}$ stretching), $3076(\mathrm{C}-\mathrm{H}$ str, aromatic), $1642(\mathrm{C}=\mathrm{N}$ str, ring) 1570-1454 $(\mathrm{C}=\mathrm{C}$ str, aromatic), 890 (C-S-C str, thiadiazole), 644 (C-Br str); ${ }^{13} \mathrm{C} \mathrm{NMR} 400 \mathrm{MHz}$, (DMSO-d $6, \delta$, ppm): 173.8 (C-5), 162.8 (C-2), 133.2 (C-1'), 131.4 (C-3',C-5'), 129.3 (C-2',C-6'), 122.8 (C-4'); LCMS (m/z): $256\left(\mathrm{M}^{+}\right), 258\left(\mathrm{M}^{+}+2\right)$; Elemental Analysis $\left(\mathrm{C}_{8} \mathrm{H}_{6} \mathrm{BrN}_{3} \mathrm{~S}\right)$, Found \% (Calculated \%): C, 37.38 (37.52); H, 2.33 (2.36); N, 16.35 (16.41); S, 12.46 (12.52).

\section{5-(4-Iodo-phenyl)-[1, 3, 4] thiadiazole-2-amine (4d)}

IR $\left(\mathrm{KBr} v, \mathrm{~cm}^{-1}\right): 3384(\mathrm{~N}-\mathrm{H}$ stretching), $3078(\mathrm{C}-\mathrm{H}$ str, aromatic $), 1643(\mathrm{C}=\mathrm{N}$ str, ring) 1572-1455 $(\mathrm{C}=\mathrm{C}$ str, aromatic), 892 (C-S-C str, thiadiazole), 534 (C-I str); ${ }^{13} \mathrm{C}$ NMR $400 \mathrm{MHz}$, (DMSO-d 6 , $\delta$, ppm): 174.2 256 
(C-5), 162.3 (C-2), 138.2 (C-3',C-5'), 132.8 (C-1'), 128.7 (C-2',C-6'), 95.1 (C-4'); LCMS (m/z): 303 $\left(\mathrm{M}^{+}\right), 304\left(\mathrm{M}^{+}+1\right)$; Elemental Analysis $\left(\mathrm{C}_{8} \mathrm{H}_{6} \mathrm{IN}_{3} \mathrm{~S}\right)$, Found \% (Calculated \%): C, 31.55 (31.70); H, 1.94 (2.00); N, 13.80 (13.86); S, 10.52 (10.58).

\section{5-(4-Methyl-phenyl)-[1, 3, 4] thiadiazole-2-amine (4e)}

IR (KBr v, $\left.\mathrm{cm}^{-1}\right)$ : 3387 (N-H stretching), 3080 (C-H str, aromatic), 2932 (C-H str, aliphatic), $1645(\mathrm{C}=\mathrm{N}$ str, ring), 1574-1460 (C=C str, aromatic), 1379 (C-H bend, aliphatic), 896 (C-S-C str, thiadiazole); ${ }^{13} \mathrm{C}$ NMR 400 MHz, (DMSO-d 6 , $\delta$, ppm): 173.7 (C-5), 162.6 (C-2), 131.5 (C-4'), 130.2 (C-1'), 128.6 (C-3',C5'), 126.4 (C-2',C-6'), $21.8\left(\mathrm{Ar}^{-} \mathrm{CH}_{3}\right)$; LCMS (m/z): $191\left(\mathrm{M}^{+}\right), 192\left(\mathrm{M}^{+}+1\right)$; Elemental Analysis $\left(\mathrm{C}_{9} \mathrm{H}_{9} \mathrm{~N}_{3} \mathrm{~S}\right)$, Found \% (Calculated \%): C, 56.38 (56.52); H, 4.70 (4.74); N, 21.92 (21.97); S, 16.72 (16.77).

\section{5-(4-Hydroxy-phenyl)-[1, 3, 4] thiadiazole-2-amine (4f)}

IR ( $\left.\mathrm{KBr} v, \mathrm{~cm}^{-1}\right): 3462(\mathrm{O}-\mathrm{H}$, stretching), $3383(\mathrm{~N}-\mathrm{H}$ str), 3077 (C-H str, aromatic), 1642 (C=N str, ring), 1570-1550 (C=C str, aromatic), 1081 (C-O str), 894 (C-S-C str, thiadiazole); ${ }^{13} \mathrm{C}$ NMR $400 \mathrm{MHz}$, (DMSO-d $6, \delta, \mathrm{ppm}): 173.2$ (C-5), 161.2 (C-2), 158.1 (C-4'), 128.3 (C-2',C-6'), 125.7 (C-1'), 115.8 (C3',C-5'); LCMS (m/z): $193\left(\mathrm{M}^{+}\right), 194\left(\mathrm{M}^{+}+1\right)$; Elemental Analysis $\left(\mathrm{C}_{8} \mathrm{H}_{7} \mathrm{~N}_{3} \mathrm{OS}\right)$, Found \% (Calculated \%): C, 49.62 (49.73); H, 3.61 (3.65); N, 21.68 (21.75); S, 16.55 (16.60).

\section{5-(4-Methoxy-phenyl)-[1, 3, 4] thiadiazole-2-amine (4g)}

IR (KBr v, cm $\left.{ }^{-1}\right): 3390$ (N-H stretching), 3081 (C-H str, aromatic), 2945 (C-H str, aliphatic), 1648 (C=N str, ring), 1576-1464 (C=C str, aromatic), 1375 (C-H bend, aliphatic), 1064 (C-O, str), 898 (C-S-C str, thiadiazole); ${ }^{13} \mathrm{C}$ NMR $400 \mathrm{MHz}$, (DMSO-d $6, \delta$, ppm): 174.2 (C-5), 162.5 (C-2), 160.4 (C-4'), 127.9 (C2',C-6'), 125.2 (C-1'), 114.3 (C-3', C-5'), $56.5\left(\right.$ Ar-O-CH3); LCMS (m/z): $207\left(\mathrm{M}^{+}\right), 208\left(\mathrm{M}^{+}+1\right)$; Elemental Analysis $\left(\mathrm{C}_{9} \mathrm{H}_{9} \mathrm{~N}_{3} \mathrm{OS}\right.$ ), Found \% (Calculated \%): C, 52.07 (52.16); H, 2.32 (4.38); N, 20.70 (20.75); S, 15.41 (15.47).

\section{5-(4-Ethoxy-phenyl)-[1, 3, 4] thiadiazole-2-amine (4h)}

IR (KBr v, cm $\left.{ }^{-1}\right): 3394$ (N-H stretching), $3084(\mathrm{C}-\mathrm{H}$ str, aromatic), 2948 (C-H str, aliphatic), $1650(\mathrm{C}=\mathrm{N}$ str, ring), 1579-1465 (C=C str, aromatic), 1383 (C-H bend, aliphatic), 1067 (C-O, str), 890 (C-S-C str, thiadiazole); ${ }^{13} \mathrm{C}$ NMR $400 \mathrm{MHz}$, (DMSO-d $6, \delta$, ppm): 174.3 (C-5), 162.4 (C-2), 158.7 (C-4'), 128.4 (C2',C-6'), 125.7 (C-1'), 115.4 (C-3',C-5'), $65.2\left(\mathrm{Ar}-\mathrm{O}-\mathrm{CH}_{2}-\mathrm{CH}_{3}\right), 15.2\left(\mathrm{Ar}-\mathrm{O}-\mathrm{CH}_{2}-\mathrm{CH}_{3}\right)$; LCMS (m/z): $221\left(\mathrm{M}^{+}\right), 222\left(\mathrm{M}^{+}+1\right)$; Elemental Analysis $\left(\mathrm{C}_{10} \mathrm{H}_{11} \mathrm{~N}_{3} \mathrm{OS}\right)$, Found \% (Calculated \%): C, 54.19 (54.28); H, 4.97 (5.01); N, 18.93 (18.99); S, 14.45 (14.49).

\section{Antimicrobial Activity}

The synthesized compounds $\mathbf{4}(\mathbf{a}-\mathbf{h})$ were evaluated for antibacterial activity against Staphylococcus aureus (MTCC7443; Gram+ve), Bacillus subtilis (MTCC121; Gram+ve), Escherichia coli (MTCC118; Gram-ve) and Pseudomonas aeruginosa (MTCC424; Gram-ve) bacterial strains ${ }^{25}$, 26 . While, the antifungal activity was tested against two fungi, Aspergillus niger and Candida albicans by disc diffusion technique ${ }^{26,27}$. Concentrations of standard drugs, Fluconazole and Ciprofloxacin $(20 \mu \mathrm{g} / \mathrm{mL})$ were used for antifungal activity and antibacterial activity, respectively.

Accurately weighed $10 \mathrm{mg}$ test compound was dissolved in dimethyl sulphoxide (DMSO) and volume made up to $10 \mathrm{~mL}$ in volumetric flask $(1.0 \mathrm{mg} / \mathrm{mL})$. This solution was further diluted with DMSO to a concentration of $100 \mu \mathrm{g} / \mathrm{mL}$. Similarly, solutions of $20 \mu \mathrm{g} / \mathrm{mLof}$ concentration of each Ciprofloxacin and Fluconazole were prepared from their stock solutions.

For Antibacterial activity, nutrient broth having composition $2.0 \mathrm{~g}$ yeast extract, $1.0 \mathrm{~g}$ beef extract $5.0 \mathrm{~g}$ peptone and $5.0 \mathrm{~g}$ of sodium chloride was added to distilled water and volume made up to $1000 \mathrm{~mL}$. Nutrient Agar medium was prepared by adding 2.0\% of agar to nutrient broth and adjusting the pH to 7.4. For antifungal studies, Sabouraud's dextrose medium having composition: peptone (10.0 g), dextrose 
$(40.0 \mathrm{~g})$ was dissolved in $1000 \mathrm{~mL}$ of distilled water and $\mathrm{pH}$ adjusted to 5.7. Finally, agar medium was prepared by adding $1.5 \%$ of agar to it.

Whatman no. 1 filter paper was employed to prepare the paper discs of about $6 \mathrm{~mm}$ in diameter. The paper discs and media were sterilized by autoclaving at $121^{\circ} \mathrm{C}$ and $15 \mathrm{lb} /$ inch pressure for 20 minutes. The agar medium was transferred to each petriplate in the aseptic conditions. A standard inoculum $\left(5 \times 10^{5}\right.$ c.f.u./mL) was properly distributed onto the surface of both sterile nutrient agar and dextrose medium plates. The sterile discs of $6 \mathrm{~mm}$ in diameter previously moistened with the standard drug or the test solutions were kept on the agar culture plates aseptically. The bacterial and fungal plates were incubated at $37 \pm 1^{\circ} \mathrm{C}$ for $24 \mathrm{~h}$ and $25 \pm 1^{\circ} \mathrm{C}$ for $72 \mathrm{~h}$ respectively. The zone of inhibition was measured and the percentage of inhibition was calculated by comparing them with standard drugs (Table-2).

Minimum inhibitory concentrations (MIC) were determined for only compounds with remarkable effects. The various concentrations of test compounds in DMSO like 90, 80, 70, 60, 50, 40, 30 and $20 \mu \mathrm{g} / \mathrm{mL}$ were first prepared and checked for inhibition. Further dilutions were made and tested till the concentration inhibiting growth was achieved (Table-3).

\section{Anticancer Activity}

Anticancer study of synthesized compounds was carried out against human breast cell line (MCF-7) using SRB (Sulfo Rhodamine-B dye) assay ${ }^{28,29}$. The cell suspensions were prepared in the appropriate growth medium to produce about $100 \mu \mathrm{L}$ volume with the cell density of $1 \times 10^{4}$ cells/well. The $100 \mu \mathrm{L}$ aliquots of cell suspensions were transferred into 96-well micro-titer plates which were incubated for $120 \mathrm{~h}$. The cell lines were kept at $37^{\circ} \mathrm{C}$ in a $5 \%$ v/v $\mathrm{CO}_{2}$ with $95 \%$ humidity. Cultures were developed within a period of 7 days and culture medium changed at least one time in the 5 days. The $100 \mu \mathrm{L}$ of culture with optimal cell density was taken in each well of 96-well titer plates. The test compounds were properly dissolved in dimethyl sulphoxide (DMSO) which was diluted to obtain various concentrations of 10, 20, 40 and 80 $\mu \mathrm{g} / \mathrm{mL} .100 \mu \mathrm{L}$ of each concentration was added to the wells containing the cell suspension and $100 \mu \mathrm{Lof}$ DMSO solvent to control cells. The cells with the test compound were incubated for $48 \mathrm{~h}$ and fixed using $100 \mu \mathrm{l}$ of cold $40 \% \mathrm{w} / \mathrm{v}$ of trichloroacetic acid at $4^{\circ} \mathrm{C}$ for $1 \mathrm{~h}$. Thereafter, the sufficient volume of cold distilled water was added to wash the plates for five times. Aliquots of $50 \mu \mathrm{L}$ of $0.4 \% \mathrm{w} / \mathrm{v}$ of SRB dye in $1 \% \mathrm{v} / \mathrm{v}$ acetic acid solution was added to each well of dried 96 well-plates and thencells were kept with dye stain for about 30 minutes. The dye was removed readily by washing the plates with $50 \mathrm{~mL}$ of $1 \% \mathrm{v} / \mathrm{v}$ acetic acid and rinsed 4-5 times till dye bonded with cells only, was retained. The $100 \mu \mathrm{L}$ of $10 \mathrm{mM}$ Tris base maintaining $\mathrm{pH} 10.5$ were added in each well of the dried plates to solubilise the contents of dye. A shaker was generally used to tremble the treated plates smoothly for 20 minutes and therefore, in each well the absorbance was read on a plate reader at $492 \mathrm{~nm}$. The same operation was done for all the samples and got the observations in triplicate as well as $\mathrm{LC}_{50}$, (drug concentration that kill the cell growth), TGI, (drug concentration that inhibit total cell growth) and $\mathrm{GI}_{50}$ values in $\mu \mathrm{g} / \mathrm{mL}$ (drug concentration that inhibit 50\% of cell growth) were determined by comparing with doxorubicin used as standard drug (Table-4).

Table- 2: Data for Antimicrobial Activityof Title compounds (4a-h)

\begin{tabular}{c|c|c|c|c|c|c}
\hline Compounds & \multicolumn{6}{|c}{ Diameter of zone of inhibition $\pm \mathrm{SD}(\mathrm{mm})^{\Theta}$} \\
\cline { 2 - 7 }$(100 \mu \mathrm{g} / \mathrm{mL})$ & S. aureus & B. substilis & E. coli & P. aureginosa & A. niger & C. albicans \\
& & & & & & \\
\hline $4(\mathrm{a})$ & $18.33 \pm 0.29$ & $18.50 \pm 0.87$ & $17.67 \pm 0.29$ & $14.33 \pm 0.29$ & $11.33 \pm 0.29$ & $10.50 \pm 0.50$ \\
& $(90.9 \%)$ & $(85.4 \%)$ & $(79.1 \%)$ & $(70.5 \%)$ & $(51.1 \%)$ & $(51.2 \%)$ \\
\hline $4(\mathrm{~b})$ & $17.17 \pm 0.29$ & $17.67 \pm 0.29$ & $16.83 \pm 0.58$ & $13.67 \pm 0.29$ & $9.67 \pm 0.58$ & $10.17 \pm 0.58$ \\
& $(85.1 \%)$ & $(81.5 \%)$ & $(75.4 \%)$ & $(67.2 \%)$ & $(43.6 \%)$ & $(49.6 \%)$ \\
\hline $4(\mathrm{c})$ & $14.17 \pm 0.58$ & $15.50 \pm 0.50$ & $14.83 \pm 0.58$ & $12.17 \pm 0.29$ & $11.50 \pm 0.50$ & $10.17 \pm 0.29$ \\
& $(70.3 \%)$ & $(71.5 \%)$ & $(66.4 \%)$ & $(59.9 \%)$ & $(51.9 \%)$ & $(49.6 \%)$ \\
\hline $4(\mathrm{~d})$ & $12.67 \pm 0.29$ & $13.83 \pm 0.58$ & $11.67 \pm 0.29$ & $11.00 \pm 0.50$ & $9.83 \pm 0.29$ & $9.50 \pm 0.50$ \\
& $(62.8 \%)$ & $(63.8 \%)$ & $(52.3 \%)$ & $(54.1 \%)$ & $(44.3 \%)$ & $(46.3 \%)$ \\
\hline
\end{tabular}

258 
RASĀYAN J. Chem.

Vol. 10 | No. 1 |254 -262 | January - March | 2017

\begin{tabular}{|c|c|c|c|c|c|c|}
\hline $4(\mathrm{e})$ & $\begin{array}{c}9.17 \pm 0.29 \\
(45.5 \%)\end{array}$ & $\begin{array}{c}9.67 \pm 0.58 \\
(44.6 \%)\end{array}$ & $\begin{array}{c}9.33 \pm 0.58 \\
(41.8 \%)\end{array}$ & $\begin{array}{c}9.33 \pm 0.58 \\
(45.9 \%)\end{array}$ & $\begin{array}{c}11.67 \pm 0.29 \\
(52.6 \%)\end{array}$ & $\begin{array}{c}11.50 \pm 0.50 \\
(56.1 \%)\end{array}$ \\
\hline $4(f)$ & $\begin{array}{c}11.50 \pm 0.50 \\
(57.0 \%)\end{array}$ & $\begin{array}{c}11.83 \pm 0.29 \\
(54.6 \%)\end{array}$ & $\begin{array}{c}13.50 \pm 0.50 \\
(60.5 \%)\end{array}$ & $\begin{array}{c}11.83 \pm 0.76 \\
(58.2 \%)\end{array}$ & $\begin{array}{c}13.00 \pm 0.50 \\
(58.6 \%)\end{array}$ & $\begin{array}{c}13.50 \pm 0.87 \\
(65.9 \%)\end{array}$ \\
\hline $4(\mathrm{~g})$ & $\begin{array}{c}11.33 \pm 0.29 \\
(56.2 \%)\end{array}$ & $\begin{array}{c}11.50 \pm 0.50 \\
(53.1 \%)\end{array}$ & $\begin{array}{c}10.50 \pm 0.50 \\
(47.0 \%)\end{array}$ & $\begin{array}{c}10.83 \pm 0.29 \\
(53.3 \%)\end{array}$ & $\begin{array}{c}12.83 \pm 0.76 \\
(57.9 \%)\end{array}$ & $\begin{array}{c}13.33 \pm 0.58 \\
(65.0 \%)\end{array}$ \\
\hline $4(h)$ & $\begin{array}{c}13.00 \pm 0.50 \\
(64.5 \%)\end{array}$ & $\begin{array}{c}13.67 \pm 0.29 \\
(63.1 \%)\end{array}$ & $\begin{array}{c}12.00 \pm 0.50 \\
(53.7 \%)\end{array}$ & $\begin{array}{c}9.50 \pm 0.50 \\
(46.7 \%)\end{array}$ & $\begin{array}{c}12.67 \pm 0.29 \\
(57.1 \%)\end{array}$ & $\begin{array}{c}12.67 \pm 0.29 \\
(61.8 \%)\end{array}$ \\
\hline $\begin{array}{c}\text { Ciprofloxacin } \\
(20 \mu \mathrm{g} / \mathrm{mL})\end{array}$ & $\begin{array}{c}20.17 \pm 0.29 \\
(100 \%)\end{array}$ & $\begin{array}{c}21.67 \pm 0.58 \\
(100 \%)\end{array}$ & $\begin{array}{c}22.33 \pm 0.76 \\
(100 \%)\end{array}$ & $\begin{array}{c}20.33 \pm 0.58 \\
(100 \%)\end{array}$ & -- & -- \\
\hline $\begin{array}{c}\text { Flucazole } \\
(20 \mu \mathrm{g} / \mathrm{mL})\end{array}$ & -- & -- & -- & -- & $\begin{array}{c}22.17 \pm 029 \\
(100 \%)\end{array}$ & $\begin{array}{c}20.50 \pm 0.50 \\
(100 \%)\end{array}$ \\
\hline DMSO & -- & -- & -- & -- & -- & -- \\
\hline
\end{tabular}

@ The percentage zone of inhibition of test compounds was calculated against various microbialstrains with reference to standard and solvent control and given as \% inhibition.

'--' indicates the zone of inhibition of control (DMSO) was considered as negligible.

Table-3: Data for Minimum Inhibitory Concentrations of Title compounds (4a-h)

\begin{tabular}{c|c|c|c|c|c|c}
\hline \multirow{2}{*}{ Compounds } & \multicolumn{7}{|c}{${ }^{\#}$ Minimum Inhibitory Concentrations (MICs), $\mu \mathrm{g} / \mathrm{mL}$} \\
\cline { 2 - 7 } & S. aureus & B. substilis & E. coli & P. aeruginosa & A. niger & C. albicans \\
\hline $4(\mathrm{a})$ & 20 & 22 & 24 & 32 & 44 & 48 \\
\hline $4(\mathrm{~b})$ & 28 & 26 & 30 & 36 & ND & ND \\
\hline $4(\mathrm{c})$ & 34 & 36 & 38 & 38 & 34 & ND \\
\hline $4(\mathrm{f})$ & 36 & 38 & 40 & 40 & 42 & 32 \\
\hline $4(\mathrm{~g})$ & $\mathrm{ND}$ & $\mathrm{ND}$ & $\mathrm{ND}$ & $\mathrm{ND}$ & $\mathrm{ND}$ & ND \\
\hline Ciprofoxacin & 18 & 20 & 20 & 24 & 26 & 24 \\
\hline Fluconazole & ND & ND & ND & ND & & \\
\hline
\end{tabular}

\# ND indicates the MIC of those compounds were not determined

Table-4: Data of Anticancer activity on Human Breast cancer cell line (MCF-7)

\begin{tabular}{c|c|c|c|c|c|c}
\hline S. No. & Compound Code & ClogP & ${ }^{a}$ LC $_{50}$ & TGI & GI $_{50}$ & ${ }^{\text {b Activity }}$ \\
\hline 1 & $4(\mathrm{a})$ & 1.63 & $>80$ & $>80$ & 46.8 & $\mathrm{Ma}$ \\
\hline 2 & $4(\mathrm{~b})$ & 2.20 & $>80$ & $>80$ & 39.3 & $\mathrm{Ma}$ \\
\hline 3 & $4(\mathrm{c})$ & 2.35 & $>80$ & $>80$ & 35.4 & $\mathrm{Ma}$ \\
\hline 4 & $4(\mathrm{f})$ & 1.11 & $>80$ & $>80$ & 24.0 & $\mathrm{Ga}$ \\
\hline 5 & $4(\mathrm{~g})$ & 1.55 & $>80$ & $>80$ & 28.1 & $\mathrm{Ga}$ \\
\hline Standard & Doxorubicin & 2.82 & $>80$ & $<10$ & $<10$ & $\mathrm{Ga}$ \\
\hline Control & DMSO & -- & -- & -- & -- & -- \\
\hline
\end{tabular}

${ }^{\mathrm{a}} \mathrm{LC}_{50}=$ drug concentration that kill the cell growth in $\mu \mathrm{g} / \mathrm{mL}$; TGI= drug concentration that inhibit total cell growth in $\mu \mathrm{g} / \mathrm{mL} ; \mathrm{GI}_{50}=$ drug concentration that inhibit $50 \%$ cell growth in $\mu \mathrm{g} / \mathrm{mL}$

${ }^{\mathbf{b}} \mathrm{Ga}$ and $\mathrm{Ma}$ indicates the good and moderate anticancer activity of potent antimicrobial agents respectively; ''indicates the activity of control was considered as negligible

\section{RESULTS AND DISCUSSION}

The 5-(4-substituted phenyl)-1,3,4-thiadiazole-2-amines were prepared by dehydrocyclization of the 4substituted benzoyl thiosemicarbazides using concentrated sulphuric acid.

Infrared, NMR, Mass spectral methods as well as elemental analysis used to elucidate the structures of all synthesized compounds. The dehydrocyclization of benzoyl thiosemicarbazides to 1,3,4-thiadiazoles was confirmed by IR absorption bands at 860 to $896 \mathrm{~cm}^{-1}$ due to the presence of C-S-C linkage of 
thiadiazoles, absorption bands from 1632 to $1650 \mathrm{~cm}^{-1}$ which are appeared because of stretching vibration of $\mathrm{C}=\mathrm{N}$ bond. Infra-red absorption bands appeared from 3372 to $3394 \mathrm{~cm}^{-1}$ due to stretching vibration of $\mathrm{N}-\mathrm{H}$ of $\mathrm{NH}_{2}$ group in the synthesized compounds. ${ }^{13} \mathrm{C}$ NMR spectra confirmed the positions of carbons (at $\delta$, ppm about 162 of C-2 and about 174 of C-5 in the thiadiazole nucleus) of the title compounds. The consistent molecular ion peaks of the synthesized compounds confirm their molecular weights and also chemical structures.

Compound 4(a) and 4(b) were found to be most active possessing bacterial inhibition between $80 \%$ to $91 \%$ as compared to Ciprofloxacin at the concentrations of $20 \mu \mathrm{g} / \mathrm{mL}$ against Staphylococcus aureus and Bacillus substilis. Compound 4(c) was moderately active showing average percentage inhibition between $70 \%$ to $75 \%$ whereas compounds $\mathbf{4 ( d )}$ and $\mathbf{4 ( h )}$ showed mild inhibitory effect ranging from $62 \%$ to $65 \%$. Rest of the compounds exhibited the inhibition from $44 \%$ to $57 \%$ considered to be inactive.

The compound 4(a), 4(b), 4(c) and 4(f) showed moderate antibacterial activity ranging between $59 \%$ to 80\% inhibition as compared to Ciprofloxacin against Escherichia coli and Pseudomonas aeruginosa. Weak activity (47\% to $55 \%$ of inhibition) was shown by compound $\mathbf{4 ( d )}$ and $\mathbf{4 ( h )}$. Compounds $\mathbf{4 ( e )}$ and 4(g) exhibited mild inhibitory action (Table-2).

Some of the compounds of the series were prominent in their action against the fungal strains i.e. Aspergillus nigerand Candida albicans. The maximum inhibitory action (57\% to 66\% inhibition) was shown by the compounds $\mathbf{4 ( f ) , ~} \mathbf{4}(\mathbf{g})$ and $\mathbf{4 ( h )}$. The remaining compounds of said series showed mild antifungal activities.

The MIC values were determined for the most potent compounds and found to be 20 to $36 \mu \mathrm{g} / \mathrm{mL}$ for Staphylococcus aureus, 22 to $38 \mu \mathrm{g} / \mathrm{mL}$ for Bacillus subtilis, 24 to $40 \mu \mathrm{g} / \mathrm{mL}$ for Escherichia coli and 32 to $40 \mu \mathrm{g} / \mathrm{mL}$ for Pseudomonas aeruginosa. Compounds 4(a), 4(b) and $\mathbf{4}$ (c) were most active antibacterial agents within the synthesized series which are less active against the Gram -ve than Gram +ve bacteria. The range of MIC was 34 to $44 \mu \mathrm{g} / \mathrm{mL}$ for Aspergillus niger and 32 to $48 \mu \mathrm{g} / \mathrm{mL}$ for Candida albicans (Table-3).

In this study, the anticancer activity of the synthesized compounds was evaluated by determining $\mathrm{LC}_{50}$, TGI, and $\mathrm{GI}_{50}$ values in $\mu \mathrm{g} / \mathrm{mL}$ using sulforhodamine-B dye method ${ }^{30}$. The compounds $4(\mathbf{f})$ possessing $\mathrm{LC}_{50}$ value $>80$; TGI value $>80$ and $\mathrm{GI}_{50}=24.0 \mu \mathrm{g} / \mathrm{mL}$ and $4(\mathrm{~g})$ with $\mathrm{LC}_{50}$ value $>80$; TGI value $>80$ and

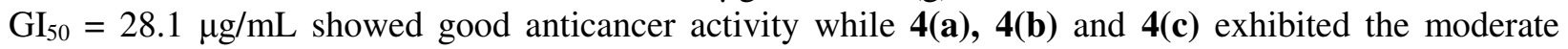
activity with same values of $\mathrm{LC}_{50}>80$; TGI values $>80$ but the $\mathrm{GI}_{50}$ values $35.4,39.3,46.8 \mu \mathrm{g} / \mathrm{mL}$ respectively.

In accordance, with the data obtained from in vitro anticancer studies, all the synthesized compounds showed moderate to good activity when compared with Doxorubicin as a standard drug. The compound 4(f) and 4(g) have shown comparatively good anticancer activity.

The value of $\operatorname{cog} P$ (determined using ChemDraw ultra 6.0) in the cytotoxic inhibition determines the permeability of drug to cross the cell membrane which should be sufficient to produce inhibitory action. From the results, it was found that the potent compounds possessing lowest clogP values showed good activity. Therefore, the cell permeability and anticancer activity of the synthesized compounds have been correlated to develop the variety of new anticancer agents. The results of anticancer activity of substituted 1, 3, 4-thiadiazoles against human breast cancer cell lines were summarized in Table-4.

In the present study, it was observed that the synthesized compound 4(a) not only ( $\mathrm{R}=4$-fluorophenyl on $\mathrm{C}-5$ position of thiadiazole nucleus) produced highest antimicrobial activity against all bacterial strains but also 4(b) and 4(c) possess significant antibacterial activity.

In contrast to this, the compounds $4(f)(R=4$-hydroxy phenyl) and $4(\mathrm{~g})(\mathrm{R}=4$-methoxy phenyl) showed slightly lower antibacterial but higher antifungal activities. The antibacterial activities of compounds 4(e) ( $\mathrm{R}=$ methylphenyl) and $\mathbf{4}(\mathrm{g})(\mathrm{R}=$ methoxyphenyl) were found to be lowest one. The antifungal activity of 4(b) and 4(d) was exceptionally lower than that of 4(f).

Analysis of structure activity relationships suggests that 4-substitution on aromatic ring at C-5 position of 1, 3, 4-thiadiazole nucleus determines antibacterial and antifungal activities. The electron withdrawing group $(\mathrm{F}, \mathrm{Cl}$ and $\mathrm{Br})$ at para position of aromatic ring on $\mathrm{C}-5$ position of thiadiazoles nucleus is necessary for potency of such antibacterial agents. 
In this study, a series of 5-(4-substituted phenyl)-1, 3, 4-thiadiazole-2-amines were synthesized. The structure-anticancer activity relationship was discovered from data that the ability of substituent at para position to withdraw or donate electrons to the phenyl ring of thiadiazoles is an essential part in such anticancer heterocyclic compounds $\mathrm{s}^{30,31}$. When an electron releasing group was substituted at the para position such as hydroxyl group in the phenyl ring (compound $\mathbf{4 f}$ ) which showed prominent anticancer activity on MCF-7 cell line. There was a replacement of the hydroxyl group (compound $\mathbf{4 f}$ ) by more electron-releasing methoxy group (compound $\mathbf{4 g}$ ) and responsible for decrease in the activity. In this relation, it may be noticed that the bulkiness of the substituent gives similar results for anticancer property. When the bulky methoxy group (compound $\mathbf{4 g}$ ) was introduced at para position by replacing the hydroxyl group (compound $\mathbf{4 f}$ ) on the aromatic ring reduces potency significantly. The compound 4(c) having bromine atom at 4-position of aromatic ring, showed improved anticancer activity when comparing with the chlorine analogs (compound 4b). Therefore, 5-phenyl 1, 3, 4-thiadiazole would be suggested as a pharmacophore for prominent anticancer activity of these bioactive compounds.

From the SAR study, it can be suggested that a most favorable electron density, the bulkiness of of 4substituent at phenyl ring on C-5 position of 1,3,4-thiadiazole may be responsible to a great extent for showing maximum anticancer property against the cell line used in this study. The presence of the hydrogen atoms attached to the amino nitrogen as a hydrogen bonding region and phenyl moiety as hydrophobic region of thiadiazoles are essential for activity. From the above discussion, it has been determined that structural alterations in 1,3, 4-thiadizoles led to more prominent antimicrobial and anticancer agents.

\section{CONCLUSION}

In summary, a simple synthetic scheme was produced for 4-substitued 5-phenyl 1,3,4-thiadiazole-2amines 4(a-h) which were elucidated by Infrared, NMR and Mass spectral techniques. All these compounds were evaluated for antimicrobial activity against different bacterial and fungal strains by disc diffusion method and anticancer activity on breast cancer cell line using SRB assay.

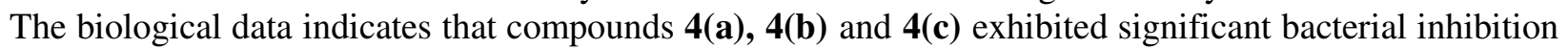
whereas compounds $\mathbf{4 ( f )}$ and $\mathbf{4}(\mathrm{g})$ showed reasonable inhibition against both fungal strains at a given concentration when compared to standard drug. The compounds $\mathbf{4 ( f )}$ and $\mathbf{4}(\mathrm{g})$ exhibited good to moderate anticancer activities.

However, these compounds could be further screened for the antibacterial activities against a variety of Gram+ve and Gram-ve bacteria to achieve their broad spectrum profile. It is possible that structural modifications of synthesized compounds will increase the antifungal activity while bioactive compounds may be further used to screen cytotoxic effect against other cell lines such as colon and lung cancer cell lines.

It is rational that further molecular modifications in these compounds will be of much interest for finding the valuable antimicrobial and anticancer agents.

\section{ACKNOWLEDGEMENT}

The authors are thankful to Instrumental facility, Faculty of Pharmacy, Jamia Hamdard, New Delhi for providing the spectral data and ACTREC, Tata Memorial Centre, Mumbai for cytotoxic studies. We are also grateful to the management of GLA University, Mathura (U.P.) for providing library and research facilities.

\section{REFERENCES}

1. M. Imran, Abida, A. Khaliq and J. Alsalman, Trop. J. Pharm. Res., 15(2), 393 (2016).

2. S. J. Gilani, S. A. Khan, N. Siddiqui, S. P. Verma, P. Mullick and O. Alam, J. Enzyme Inhib. Med. Chem., 26(3), 332 (2011).

3. P. Mullick, S. A. Khan, S. P. Verma and O. Alam, Bull. Korean Chem. Soc., 31(8), 2345 (2010).

4. V. Padmavathi, A.V. Nagendra Mohan, P. Thriveni and V. Shazia, Eur. J. Med. Chem., 44(4), 2313 (2009).

5. P. Zhao, A. Duan, M. Zou, H. Yang, W. You and S. Wu, Bioorg. Med. Chem. Lett., 22, 4471 (2012). 
RASĀYAN J. Chem.

Vol. 10 | No. 1 | 254 -262 | January - March | 2017

6. A. Almasirad, L. Firoozpour, M. Nejati, N. Edraki, O. Firuzi, M. Khoshneviszadeh, M. Mahdavi, S. Moghimi, M. Safavi, A. Shafiee and A. Foroumadi, Z. Naturforsch.,71(3)b, 205 (2016).

7. N. Terzioglu and A. Gursoy, Eur. J. Med. Chem., 38, 781 (2013).

8. S. F. Barbuceanu, G. Saramet, G. L. Almajan, C. D. F. Barbuceanu and G. Bancescu, Eur. J. Med. Chem., 49, 417 (2012).

9. S. Kerura, K. Alagawadi, H. Zhu and F. Manvi, Eur. J. Med. Chem., 3(3), 293 (2012).

10. V. Padmavathi, G. S. Reddy, A. Padmaja, P. Kondaiah and A. Shazia, Eur. J. Med. Chem., 44(5), 2106 (2009).

11. A. K. Gadad, M. N. Noolvi and R. V. Karpoormath, Bioorg. Med. Chem., 12(21), 5651 (2004).

12. S. G. Alegaon, K. R. Alagawadi, P. V. Sonkusare, S. M. Chaudhary, D. H. Dadwe and A. S. Shah, Bioorg. Med. Chem. Lett., 22(5), 1917 (2012).

13. K. G. Andanappa, B. P. Mahesh, K. Anand, N. N. Malleshappa, S. B. Thippeswamy and J. Wagwade, Bioorg. Med. Chem., 16, 276 (2008).

14. V. K. Bhovi and Y. D. Bodke, Curr. Chem. Biol., 4(2), 145 (2010).

15. C. B. Chapleo, M. Myers, P. L. Myers, J. F. Saville, A. C. B. Smith, M. R. Stillings, I. F. Tulloch, D. S. Walter and A. P. Welbourn, J. Med. Chem., 29(11), 2273 (1986).

16. S. Turner, M. Myers, B. Gadie, S. A. Hale, A. Horsley, A. J. Nelson, R. Pape, J. F. Saville, J. C. Doxey and T. L. Berridge, J. Med. Chem., 31(5), 906 (1988).

17. I. T. Barnish, P. E. Cross, R. P. Dickinson, B. Gadsby, M. J. Parry, M. J. Randall and I. W. Sinclair, J. Med. Chem., 23, 117 (1980).

18. G. Mazzone, R. Pignatello, S. Mazzone, A. Panico, G. Penisi, R. Castana and P. Mazzone, Farmaco, 48(9), 1207 (1993).

19. S. Dhanya, A. M. Isloor, P. Shetty, P. Satyamoorthy and A. S. Bharath Prasad, Arabian J. Chem., 3, $211(2010)$.

20. B. S. Furniss, A. J. Hannaford, V. Rogers, P. W. G. Smith and A. R. Tatchell, Vogel's Textbook of Practical Organic Chemistry, Pearson Pvt Ltd, Delhi, p.781 (2005).

21. H. Johne,K. Seifert, S. Johne and E. Bulka, Pharmazie, 33(5), 259 (1978).

22. C. Ainsworth, J. Am. Chem. Soc., 78(9), 1973 (1956).

23. M. R. Aouad, M. Messali, N. Rezki, A. A. Ali and A. Lesimple, Acta Pharm., 65, 117 (2015).

24. S. L. Vasoya, D. J. Paghdar, P. T. Chovatia and H. S. Joshi, J. Sci. I. R. Iran., 16(1), 33 (2005).

25. K. R. Aneja, Experiments in Microbiology: Plant Pathology and Biotechnology, New Age International (P) Ltd Publishers, New Delhi, p.580 (2007).

26. M. Imran, Abida and S. A. Khan, Trop. J. Pharm. Res., 14(7), 1265 (2015).

27. R. S. Varma, Z. K. Khan and A. P. Singh, Antifungal agents: past, present, future prospects, National Academy of Chemistry and Biology, Lucknow, p.55 (1998)

28. P. Skehan, R. Storeng, D. Scudiero, A. Monks, J. McMahon, D. Vistica, J. T. Waren, H. Bokesh, S. Kenney and M. R. Boyd, J. Natl. Cancer Inst., 82(17), 1107 (1990).

29. P. Houghton, R. Fang, I. Techatanawat, G. Steventon, P. J. Hylands and C. C. Lee, Methods, 42, 377 (2007).

30. G. Tegginamath, R. R. Kamble, T. Taj, P. P. Kattimani and G. Y. Meti, Med. Chem. Res., 22(9), 4367 (2013).

31. M. Sayed, Alam, L. Liu and D. U. Lee, Chem. Pharm. Bull., 59(11), 1413 (2011).

[RJC-1573/2017] 